Insect biochemistry

Biochemistry of Insects. Edited by M. Rockstein. Pp. 649. (Academic: New York, San Francisco and London, 1978.) \$29.50; £19.15.

IN 1961 Darcy Gilmour's book The Biochemistry of Insects (Academic: London) was published and in a text of under 300 pages it covered the available information on insect biochemistry, and included a generous amount of background information on general biochemical principles. The growth of the subject in the intervening years has been prodigious and to effectively review the field in a book that is little more than twice the size of Gilmour's is no mean achievement. The book that Morris Rockstein has edited covers the ground admirably. Its production and format closely resembles the six-volume revision of The Physiology of the Insecta produced by the same editor and publisher in 1974, and these two works will stand as a major source for entomology students for many years to come.

The majority of undergraduates who undertake specialist entomology courses these days will have received some basic biochemical training and this is essential if maximum benefit is to be derived from this book. However, it is not simply an exposition of the biochemical specialisations to be found in the Insecta. The authors have each taken the trouble to fit the biochemical facts into the wider biological picture and no matter what aspect of entomology interests the reader, he or she will find valuable facts and ideas within this book.

Inevitably, in any work which is compiled from several contributing authors there is some lack of uniformity in approach. To quote one example, the chapters on carbohydrates and lipids deal with the nutritional requirements for these compounds, and with their digestion and absorption, but no corresponding information is available in the chapters on proteins and amino acids. A lack of uniformity is also evident in the references to original literature, the chapter on insect biochromes having a bibliography of more than 30 general references and about 140 specialist references, whereas that on the toxic action of insecticides has only five general references. The separate listing of general works in the bibliographies is an admirable idea for the undergraduate reader interested solely in reviewing a particular topic. On the other hand the postgraduate reader who consults those chapters where specialist references are lacking, will require access to several other reference works before the original papers can be tracked down.

This very readable book is a valuable and significant contribution to the entomological literature. It provides important background information for

\section{Biochemistry of viruses}

The Biochemistry of Viruses. By S. J. Martin. Pp. 145. (Cambridge University Press: Cambridge, 1978.) Hardback $£ 10.50$; paperback $£ 3.95$.

KNOWLEDGE of the nature and biosynthesis of viruses has progressed to a stage where it is clearly impossible to encompass all aspects of the biochemistry of viruses in the space of 145 pages. The author of this latest volume in the series Cambridge Texts in Chemistry and Biochemistry has adopted a sensible compromise presenting a coherent survey of the subject based largely on his own experience and interests. The text progresses from a brief but adequate review of the history of virology through chapters on classification, assay, purification, structure, strategy of infection (that is, transcription, replication, maturation, defectiveness), therapeutic and prophylactic agents, and evolution. The book begins and ends on a philosophical note contrasting the virus as the invader of the genosphere with man as the invader of the biosphere.

The best and most comprehensive portion of the book is the chapter on virus architecture. The chapter on strategy of infection, which takes up 54 of the 145 pages, is well written but is less satisfactory, as it fails to deal adequately with the animal DNA viruses and the RNA tumour viruses. The text also suffers from having been prepared before the application of restriction endonucleases to analysis of

\section{Molecular genetics}

THERE have been three exceptional textbooks written about microbial genetics. These are The Genetics of Bacteria and their Viruses by W. Hayes first published in 1964, The Molecular Biology of the Gene by J. Watson first published in 1968, and Molecular Genetics by G. Stent which was first published in 1971. These books cover a lot of similar territory, but each has a distinctive flavour. In Hayes' treatment the development of the subject undergraduate courses and will be a standard reference work for a wide range of professional entomologists.

John B. Ford

John B. Ford is Senior Lecturer in Entomology in the Department of Applied Zoology at the University College of North Wales, Bangor, UK.

the structure of the genomes of DNA viruses. In my view these deficiencies, together with the virtual exclusion of genetics, will limit the usefulness of this book as a course textbook. It can be recommended, however, as supplementary reading because Dr Martin has a lucid and simple style of writing which provides the hard-pressed student with an excellent example of the organisation and presentation of information in essay form.

Over-simplification occasionally generates inaccuracies such as "all RNA tumour viruses... appear to have similar base sequences" (p123); "most DNA viruses contain circular DNA molecules" (p44); and the like. Also a number of errors have slipped through. For instance, part of Figure 5.26 is missing; two eminent virologists have their names mis-spelt; the molecular weight of herpes simplex virus DNA is given variously as 54.92 (Fig. 2.4), 75 (p92) and 80-100 (Appendix) million and that of oncornavirus RNA as 10 million (Fig. 2.5). The retroviruses do not appear in the virus classification in the Appendix, apart from Rous Sarcoma virus which is listed as the prototype of the genus coronavirus of the family rhabdoviridae!

These imperfections will be sufficiently obvious to most readers not to detract from the basic worth of the book as a simple introduction to the biochemistry of viruses.

\section{R. Pringle}

C. R. Pringle is a member of the scientific staff of the Medical Research Council Virology Unit in the Institute of Virology, University of Glasgow, UK. seems a trifle disorganised in places, but the book is written with a sense of enthusiasm and wonder which is quite infectious. Watson's approach is autocratic, or "sovereign didactic" to quote the felicitous if somewhat ambiguous description from Stent. One has the feeling that no matter how cells originally functioned that after reading Watson's book they would have considered it advisable to conform to the royal dogma. Stent's book is undoubtedly the most literary of the three. He set out to write an introductory narrative and the book tells the story superlatively well.

Of these books Hayes came out in a 